\title{
Cladoceran community structure in three meso-eutrophic Polish lakes with varying thermal regimes
}

\author{
Irina Yu. Feniova ${ }^{1, *}$, Vladimir I. Razlutskij ${ }^{2}$, Anna L. Palash ${ }^{2}$, JacekTunowsky ${ }^{3}$, \\ Elena A. Sysova ${ }^{2}$ and Andrew R. Dzialowski ${ }^{4}$
}

${ }^{1}$ A. N. Severtsov Institute of Ecology and Evolution, Russian Academy of Sciences, Leninsky pr., 33, 119071 Moscow, Russia.

2 The Scientific and Practical Center for Bioresources, National Academy of Sciences of Belarus, str. Akademicheskaya, 27, 220072 Minsk, Republic of Belarus.

${ }^{3}$ Institute of Inland Fisheries, str. Oczapowskiego, 10, 10-719, Olsztyn, Poland.

${ }^{4}$ Oklahoma State University, Department of Zoology, Stillwater, OK, USA.

* Corresponding author: feniova@mail.ru

Received: 23/01/2013

Accepted: 10/12/2013

\begin{abstract}
Cladoceran community structure in three meso-eutrophic Polish lakes with varying thermal regimes

The effects of temperature on cladoceran community structure are not well understood. We assessed the dynamics of cladoceran communities in three meso-eutrophic Polish lakes within the same region but with different thermal regimes. In an artificially (power plant) heated lake, Daphnia were absent during the warmest period in July. In the two other lakes, one of which was secondarily heated and one that was non-heated, Daphnia accounted for 19-36\% of the total biomass of the cladoceran communities. Species richness was also higher in the non-heated and secondarily heated lakes than in the heated lake. Phytoplankton analysis suggested that cyanobacteria did not suppress Daphnia, as the highest relative abundance of Daphnia was observed in the non-heated lake, which also presented the highest relative abundance of cyanobacteria. Additionally, there was no indication that food depletion was greater in the heated lake than in the other two lakes. A contribution analysis to estimate bottom-up and top-down effects showed that predation was more important in controlling cladoceran birth rates in the non-heated lake compared to the other two lakes. Daphnia abundance declined with heating, while the abundance of smaller-bodied species, including Ceriodaphnia and Diaphanosoma, increased. We suggest that increased mortality due to the increased temperature in the heated lake may have been the cause of Daphnia suppression compared to the other two study lakes.
\end{abstract}

Key words: Zooplankton, phytoplankton, Daphnia, cyanobacteria, field studies, population parameters, contribution analysis.

\section{RESUMEN}

Estructura de la comunidad de cladóceros en tres lagos meso-tróficos de Polonia con diferentes regímenes de temperatura

Evaluamos la dinámica de la comunidad de cladóceros en tres lagos meso-tróficos de Polonia, de la misma región pero con diferentes regímenes de temperatura. En un lago calentado artificialmente (central térmica) Daphnia estuvo ausente durante el periodo más cálido, en Julio. En los otros dos lagos, uno conectado con el anterior y por tanto, calentado indirectamente y otro que no lo fue, Daphnia representó el 19-36 \% del total de la comunidad de cladóceros. La riqueza de especies fue también más alta en el lago no calentado y el calentado secundariamente, que en el primero. El análisis del fitoplancton mostró que las cianobacterias no ejercieron ningún efecto negativo en la abundancia de Daphnia, ya que el lago no calentado presentó la abundancia relativa más alta de este género y además la mayor abundancia relativa de cianobacterias. Adicionalmente, no hubo ningún indicio de que hubiera una mayor disminución de alimento en el lago calentado artificialmente que en los otros dos lagos. Con un análisis de contribución, para estimar los efectos bottom-up y top-down, se demostró que la depredación fue más importante en el control de las tasas de nacimiento de los cladóceros en el lago no calentado que en los otros dos lagos. La abundancia de Daphnia decreció con el calentamiento, mientras que especies de menor tamaño, como Ceriodaphnia y Diaphanosoma, aumentaron su abundancia. El incremento de la temperatura en el lago calentado artificialmente, pudo ser la causa del aumento de la mortalidad de Daphnia respecto a los otros dos lagos. 
Palabras clave: Zooplancton, fitoplancton, Daphnia, cianobacterias, estudios de campo, parámetros de la población, análisis de contribución.

\section{INTRODUCTION}

Global climate change has been identified as a major threat to native biodiversity (Brooker $e t$ al., 2007). Elevated temperature can induce increases in primary production due to the intensification of photosynthetic activity (Magnuson et al., 1997; Finlay, Finlay et al., 2001; Karlsson et al., 2005, Petchey et al., 1999). Under warmer conditions, the biomass of phytoplankton is predicted to increase, while that of zooplankton is predicted to decrease (Holzapfel \& Vinebrooke, 2005). In Lake Windermere, George \& Harris (1985) found an inverse correlation between the summer crustacean biomass and temperature. However, there are several studies that contradict these findings. For example, a $3{ }^{\circ} \mathrm{C}$ increase in the temperature of shallow ponds was not observed to affect the biomass of cladocerans, which instead appeared to be controlled mainly by fish predation and nutrient loading (McKee et al., 2002). Similar conclusions were drawn by Gyllostrom et al. (2005) based on their analysis of data from 81 shallow European lakes located in various climate zones. Specifically, they found that the biomass and community structure of zooplankton were driven mostly by phosphorus loading. In another study, climate effects were shown to be positively related to fish biomass and the ratio of fish to zooplankton (Gyllström et al., 2005). Nevertheless, an experimental increase of $3.6{ }^{\circ} \mathrm{C}$ in mesocosms located next to fishless alpine ponds significantly decreased the total zooplankton biomass, while phytoplankton biomass was not affected (Streckeret al., 2004).

As high temperatures accelerate physiological processes, a deficit in food resources may occur in heated waters. Beisner et al. (1997) found that a temperature increase from $18{ }^{\circ} \mathrm{C}$ to $25^{\circ} \mathrm{C}$ accelerated the population growth rate of Daphnia in experimental mesocosms, resulting in a sharp decline in the abundance of algal food re- sources, consequently leading to the extinction of Daphnia. The abundance of phytoplankton in these experiments increased mainly due to the growth of grazer-resistant filamentous cyanobacteria. Thus, experimental and field studies suggest that changes in temperature have the potential to impact zooplankton and phytoplankton. However, it remains unclear whether temperature directly affects zooplankton or if these effects are indirectly mediated through biotic relationships (e.g., increase in the abundance of cyanobacteria under warmer conditions).

Moore et al. (1996) hypothesised that largebodied species exhibit upper thermal tolerances that are lower than those of the small-bodied species. Hence, large-bodied species would be expected to be replaced by small-bodied species at higher temperatures, while small-bodied species would be replaced at lower temperatures. In support of this notion, there is evidence that higher temperatures favour the development of small species and suppress the development of large species (Gillooly et al., 2002; Feniova et al., 2013). Temperature-mediated shifts in competition between small- and large-bodied species may help to explain the success of the relatively small-bodied Daphnia lumholtzi Sars in US lakes in the late summer, when water temperatures are at their highest (Lennon et al., 2001). Subtropical and tropical lakes also tend to be dominated by small-bodied zooplankton taxa, such as Ceriodaphnia and Diaphanosoma, suggesting that small-bodied cladocerans are favoured in warm water compared to largebodied cladocerans (Atkinson, 1994; Sarma et al, 2005; Pinto-Coelho et al., 2005; Meerhoff et al., 2007). However, it is important to note that factors other than temperature may contribute to dominance by small-bodied taxa in these systems (e.g., different predation pressures). Furthermore, several experimental studies have found that large-bodied species are more com- 
petitive than small-bodied species, regardless of temperature (Gliwicz, 2003; Achenbach \& Lampert, 1997). Thus, the mechanisms that alter the size-structure and composition of cladoceran communities in lakes under warming conditions remain unclear.

The aim of this study was to determine how the species composition and biomass of cladoceran communities varied in three mesoeutrophic lakes with different thermal regimes located in the Konin lakes area of Poland. We utilised a unique situation in which one of the study lakes was directly heated by a power plant, while one of the lakes was secondarily heated by the power plant (e.g., it was connected by a canal to the heated lake), and the third lake was not heated but was located in close proximity to the two heated lakes. Although studies have been performed in the Konin lakes since the 1960s (Patalas, 1967; Poltoracka-Sosnowska, 1967; Hillbricht-Ilkowska \& Zdanowski, 1978, 1988; Tunowski, 1988, 2009a, b; Ejsmont-Karabin \& Wegleńska, 1988; Napiórkowska-Krzebietke, 2009), it is still unclear what factors structure their zooplankton communities. Heating as a result of operating power plants can affect the zooplankton structure directly or indirectly through accompanying factors such as decreases in retention time (Hillbricht-Ilkowska \& Zdanowski, 1988; Tunowski, 1988, 2009a) and increase of phytoplankton biomass (Hillbricht-Ilkowska \& Zdanowski, 1988). Additionally, while fish predation can be an important factor controlling zooplankton communities, studies on the fish population structure in the Konin lakes conducted from 1966 to 2000 indicated that the ichthyo- fauna composition is relatively similar between the lakes (Tereshchenko et al., 2007b). The substantial similarity in the ichthyofaunal composition results, at least in part, from the lack of spatial isolation between the lakes, which is an important factor that influences the fish stocking structure (Olden et al., 2001). Thus, we expected predation pressure to be similar in these lakes. The main goal of this study was to establish how temperature affected cladocerans in the three lakes, with careful consideration of additional controlling factors, including food availability and fish predation pressure.

\section{METHODS}

While the thermal regimes vary in the three lakes, they are relatively similar with respect to size and depth (Table 1). The heated lake (Lake Licheńskie, $52^{\circ} 18^{\prime} \mathrm{N}, 18^{\circ} 20^{\prime} \mathrm{E}$ ) is a small, mesoeutrophic lake heated year-round by discharged waters from the Konin power plant. Our secondarily heated lake (Lake Ślesińskie, $52^{\circ} 23^{\prime} \mathrm{N}$, $\left.18^{\circ} 19^{\prime} \mathrm{E}\right)$ is connected to the heated lake by a canal (Tereshchenko et al., 2007 a). Lake Ślesińskie receives heated water that is pumped from Lake Licheńskie from May to September, which reduces the water retention time in Lake Licheńskie (Table 1; Stawecki et al., 2007).

Long-term (1995-2004) studies have shown that the temperature in Lake Licheńskie is $2-5^{\circ} \mathrm{C}$ greater year-round than it is in Lake Ślesińskie (Stawecki et al., 2007). Our third, non-heated

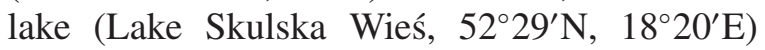
does not experience temperature loading and was

Table 1. General characteristics of the three studied lakes. Características generales de los tres lagos estudiados.

\begin{tabular}{lccc}
\hline & Licheńskie & Ślesińskie & Skulska Wieś \\
\hline Area (ha) & 153.6 & 148.1 & 124.3 \\
Max. depth (m) & 13.3 & 25.7 & 17.5 \\
Mean depth (m) & 4.9 & 7.5 & 6.5 \\
Retention time (day) & $3-5$ & 1.3 & $14-30$ \\
Mean $\mathrm{N}_{\text {tot }}$ content $\left(\mathrm{mg} \mathrm{L}^{-1}\right)$ & 1.3 & 0.099 & 3.5 \\
Mean $\mathrm{P}_{\text {tot }}$ content $\left(\mathrm{mg} \mathrm{L}^{-1}\right)$ & 0.089 & meso-eutrophic & 0.06 \\
Trophic type & meso-eutrophic & meso-eutrophic \\
\hline
\end{tabular}




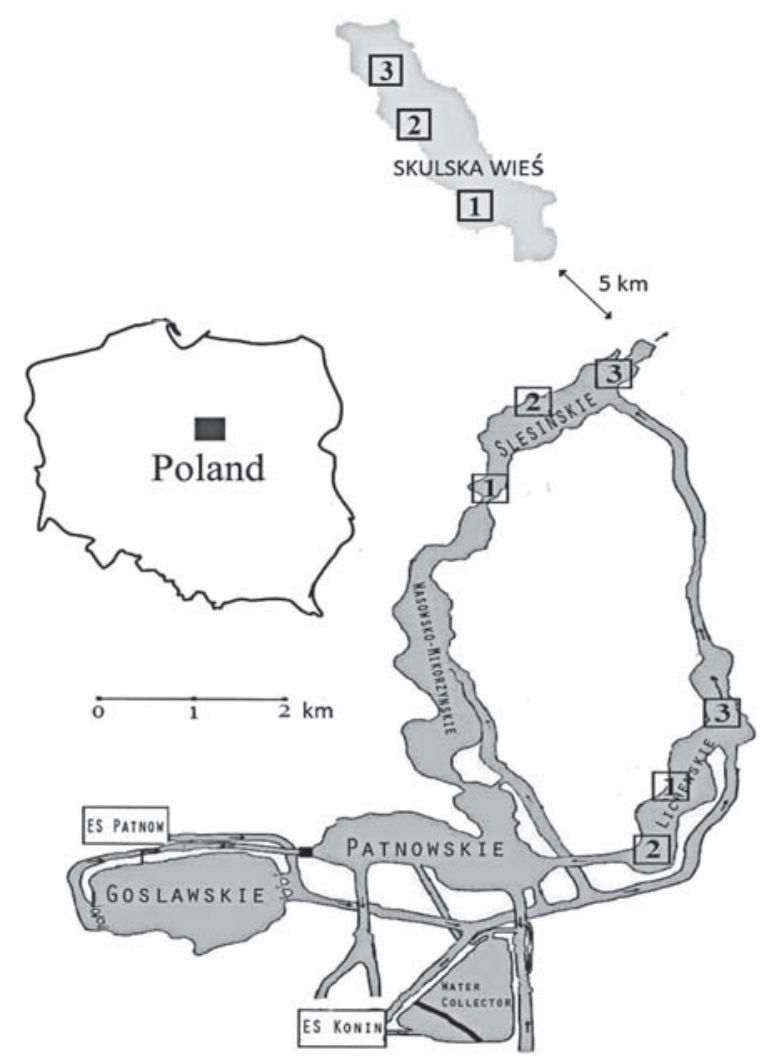

Figure 1. Diagram of the lakes heated by the Konin power plant (modified from Sinicyna et al., 2001). The sampling stations are shown in the numbered boxes. The third lake, Skulska Wieś, was located approximately $5 \mathrm{~km}$ north of the heated Konin lakes. Diagrama de los lagos calentados por la planta Konin (modificado de Sinicyna et al., 2001). Las estaciones de muestreo corresponden a las cajas numeradas. El tercer lago, Skulska Wieś, se encontraba localizado aproximadamente $5 \mathrm{~km}$ al norte de los lagos calentados por la planta Konin.

used as a control for studying the effects of temperature on the composition and structure of cladoceran communities in the heated lakes (Fig. 1).

Some previous data exist for fish and zooplankton in the Konin lakes system. The fish occurring at the highest abundance were found to belong to the Ponto-Caspian complex. Considering thermal requirements, the best numerically represented species are thermophilic (15 species), and 3 species are eurythermic. Fisheries in the system are based on roach, Rutilus rutilus (L.), bream, Abramis brama (L.), and white bream, Abramis bjoerkna (L.), as well as the Asian cyprinid grass carp, Ctenopharyngodon idella (Val.), silver carp, Hypophthamichtys molitrix (Val.), and bighead carp, Aristichthys nobilis (Richardson) (Tereshchenko et al., 2007b).

Before Lake Ślesińskie was included in the water cooling system, the zooplankton biomass in the lake in summer ranged from 1.5 to $4.0 \mathrm{mg}$ $\mathrm{L}^{-1}$ (wet weight) and was lower than in May (approximately $25 \mathrm{mg} \mathrm{L}^{-1}$ ) (Tunowski, 2009a). In Lake Licheńskie, the zooplankton biomass in the summer was lower $\left(<0.5 \mathrm{mg} \mathrm{L}^{-1}\right)$, increasing in the spring to $1.2 \mathrm{mg} \mathrm{L}^{-1}$. In lakes Ślesińskie and Licheńskie, Copepoda did not exceed $10 \%$ of the total zooplankton biomass, and Rotifera did not exceed $6 \%$. Cladocerans comprised between 60 $90 \%$ of the overall zooplankton biomass in these lakes (Tunowski, 2009a). Based on these data, we focused the current study only on cladocerans. Lake Skulska Wieś has not been as well studied as the other two lakes. However, because it is located in close spatial proximity to the other two lakes, we assumed that the zooplankton and fish communities were recruited from the same species pool.

Samples were collected from three stations in each lake in July (20.07.2010-31.07.2010) and August-September (24.08.2010-4.09.2010) at threeday intervals (totally 8 dates), which were staggered for the three lakes. The locations of the three sampling stations in each studied lake are shown in Figure 1. A total of 12 samples were collected from each lake in July, and 12 samples were collected from each lake in August-September. Temperature and dissolved oxygen were measured at $1 \mathrm{~m}$ intervals from the bottom of each lake to the surface using a YSI 5740 Dissolved Oxygen and Temperature Probe (Yellow Springs Instruments Co, Inc., Yellow Springs, Ohio, USA).

Zooplankton samples were collected from each station at midday by lowering a zooplankton net $\left(0.05 \mathrm{~m}^{2}\right.$ opening, $\left.70 \mu \mathrm{m}\right)$ to the bottom of the metalimnion and then pulling it to the surface. We collected our samples from the metalimnion and epilimnion because few individuals migrate into the hypolimnion and the hypolimnetic abundance is insignificant compared to the total abundance of zooplankton in the lakes (personal observation). The samples were preserved in a 
Table 2. Average biomass (mg, wet weight) of adult females of different cladoceran species at the onset of maturity. The species are arranged from smallest to largest based on biomass. Data from unpublished laboratory experiments (Palash \& Feniova). Biomasa promedio ( $\mathrm{mg}$, peso fresco) de las hembras adultas para las diferentes especies de cladóceros, en el inicio de la madurez. Las especies están ordenadas de menor a mayor tamaño a partir de la biomasa. Datos a partir de experimentos de laboratorio no publicados (Palash \& Feniova).

\begin{tabular}{lcc}
\hline & Biomass & st. error \\
\hline Daphnia galeata (Sars) & 0.027 & 0.0035 \\
Daphnia longispina (O. F. Müller) & 0.023 & 0.0015 \\
Daphnia hyalina (Leydig) & 0.022 & 0.0010 \\
Daphnia cucullata (Sars) & 0.018 & 0.0008 \\
Ceriodaphnia reticulata (Jurine) & 0.016 & 0.0006 \\
Ceriodaphnia quadrangula (O. F. Müller) & 0.014 & 0.0010 \\
Diaphanosoma brachyurum(Liéven) & 0.012 & 0.0006 \\
Bosmina crassicornis (O. F. Müller) & 0.012 & 0.0010 \\
Ceriodaphnia pulchella (Sars) & 0.011 & 0.0041 \\
Bosmina longispina (Leydig) & 0.010 & 0.0008 \\
Bosmina coregoni (Baird) & 0.009 & 0.0003 \\
Pleuroxus aduncus (Jurine) & 0.008 & 0.0006 \\
Chydorus sphaericus (O. F. Müller) & 0.005 & 0.0001 \\
Bosmina longirostris (O.F.Müller) & 0.003 & 0.0003 \\
\hline
\end{tabular}

$0.5 \%$ formaldehyde solution. Sugar $\left(40 \mathrm{~g} \mathrm{~L}^{-1}\right)$ was added to each sample to avoid egg losses. Zooplankton were subsampled such that at least 100 individuals were counted in each sample. A minimum of 50 individuals of each identified species of cladoceran was measured to estimate biomass using length-weight relationships from Balushkina \& Winberg (1978). We also measured the number of eggs per individual to obtain estimates of fecundity (average clutch size), and we estimated birth and death rates based on Paloheimo (1974; see below) and summarised the biomass of all species within the genera Daphnia, Bosmina, and Ceriodaphnia individually. Phytoplankton samples were collected using a 5-litre semi-automatic Toñ sampler from depths of 0.5 , 1.0 , and $2.0 \mathrm{~m}$ and combined into composite samples. During each of the July sampling dates, the phytoplankton collected from the three stations were combined into composite samples for each lake. For both zooplankton and phytoplankton, individuals were identified to the species level.

Because we distinguished between small- and large-bodied cladoceran species, we arranged the species in a size gradient based on their body mass (mg) at the onset of maturity (Table 2). The average biomass (mg, wet weight) of adult females of the different cladoceran species were determined using laboratory-reared zooplankton at the onset of maturity when eggs were first released into the brood chamber (Palash \& Feniova, unpublished data). We compared the averaged biomass values for D. brachyurum and Daphnia sp., Bosmina sp., and Ceriodaphnia sp. between the lakes and between warmer (July) and colder (August-September) periods. The Daphnia species were larger than the other species found in the lakes (Table 2). Although Daphnia cucullata (Sars) was the smallest Daphnia species identified, we included it in the Daphnia group because it shows similar population characteristics. We also compared the total biomass of cladocerans between the lakes and sampling periods. Although Daphnia is generally a non-

Table 3. Fecundity (mean clutch size), death rate $\left(\right.$ day $\left.^{-1}\right)$, and population growth rate $\left(\mathrm{r} \mathrm{day}^{-1}\right)$ in the tree studied lakes in July and August-September. Fecundidad (tamaño medio de puesta), tasa de mortalidad (día ${ }^{-1}$ ) y tasa de crecimiento de la población ( $r$ día ${ }^{-1}$ ) en los tres lagos estudiados en julio y agosto-septiembre.

\begin{tabular}{|c|c|c|c|c|c|c|c|c|c|c|}
\hline & & \multicolumn{3}{|c|}{ Licheńskie } & \multicolumn{3}{|c|}{ Ślesińskie } & \multicolumn{3}{|c|}{ Skulska Wieś } \\
\hline & & $\begin{array}{c}\text { Fecundity } \\
\text { (mean clutch size) }\end{array}$ & $\begin{array}{l}\text { Death Rate } \\
\left(\text { day }^{-1}\right)\end{array}$ & $\begin{array}{c}r \\
\left(\text { day }^{-1}\right)\end{array}$ & $\begin{array}{c}\text { Fecundity } \\
\text { mean clutch size) }\end{array}$ & $\begin{array}{l}\text { Death Rate } \\
\quad\left(\text { day }^{-1}\right)\end{array}$ & $\begin{array}{c}r \\
\left(\text { day }^{-1}\right)\end{array}$ & $\begin{array}{c}\text { Fecundity } \\
(\text { mean clutch size })\end{array}$ & $\begin{array}{l}\text { Death Rate } \\
\left(\text { day }^{-1}\right)\end{array}$ & $\begin{array}{l}\mathbf{r} \\
\left(\text { day }^{-1}\right)\end{array}$ \\
\hline \multirow{3}{*}{ 를 } & Daphnia sp. & & & & 2.4 & 0.27 & 0.02 & 1.9 & 0.1 & 0.07 \\
\hline & Small species & 2.2 & 0.22 & -0.33 & 1.9 & 0.12 & 0.05 & 1.5 & 0 & 0.12 \\
\hline & Average & & & & 2.1 & 0.19 & 0.03 & 1.7 & 0.05 & 0.09 \\
\hline \multirow{3}{*}{ 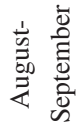 } & Daphnia sp. & & & 0.18 & 2.7 & 0.16 & -0.05 & 1.7 & 0.01 & 0.04 \\
\hline & Small species & 2.1 & 0.26 & -0.14 & 2.1 & 0.17 & -0.05 & 1.5 & 0.04 & 0.01 \\
\hline & Average & & & 0.02 & 2.4 & 0.16 & -0.05 & 1.6 & 0.02 & 0.02 \\
\hline
\end{tabular}


selective filter feeder, there is a size range of particles that it can ingest (Lampert, 1987). The size ranges for edible algae vary between and within species, depending on the size of the zooplankter (Burns, 1969), but particles $>40 \mu \mathrm{m}$ are generally difficult to consume, both in nature (Bloem \& Vijverberg, 1984) and the laboratory (Dawidowicz, 1990). Therefore, we separated potentially edible $(<40 \mu \mathrm{m})$ and non-edible $(>40 \mu \mathrm{m})$ phytoplankton biomass.

We also estimated the relative roles of topdown (predation) and bottom-up (food) effects on cladocerans in the studied lakes using methods developed by Polishchuk (1995) and Polishchuk et al. (2012). This approach estimates the contribution of the proportion of adults $(A)$ and the mean clutch size $(F)$ to a change in birth rate. The birth rate was determined according to a modi- fied form of Edmondson and Palaheimo's equation (Paloheimo, 1974):

$$
b=V \ln (1+F A)
$$

where $b=$ the instantaneous per capita birth rate $\left(d^{-l}\right) ; V=$ the egg development rate $\left(d^{-l}\right)$, which is the reciprocal of the egg development time; $F=$ the mean clutch size of adults (i.e., the ratio of the number of eggs, $E$, to the number of adults, $N_{\text {ad }}$ ); and $A$ is the proportion of adults within the whole population $\left(A=N_{\mathrm{ad}} / N\right)$, where $N=$ total number of individuals. The product $F A$ equals $E / N$, which returns Eq. 1 to the conventional form of the Edmondson-Paloheimo model (Paloheimo, 1974). When only $F$ determines the birth rate, the food conditions can be considered to be responsible for the birth rate val-
A. Dissolved Oxygen $\left(\mathrm{mg} \mathrm{L}^{-1}\right)$ and Temperature $\left({ }^{\circ} \mathrm{C}\right)$

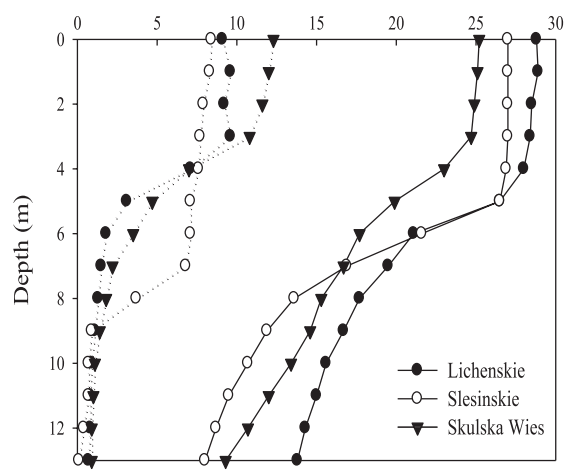

C. Dissolved Oxygen $\left(\mathrm{mg} \mathrm{L}^{-1}\right)$ and Temperature $\left({ }^{\circ} \mathrm{C}\right)$

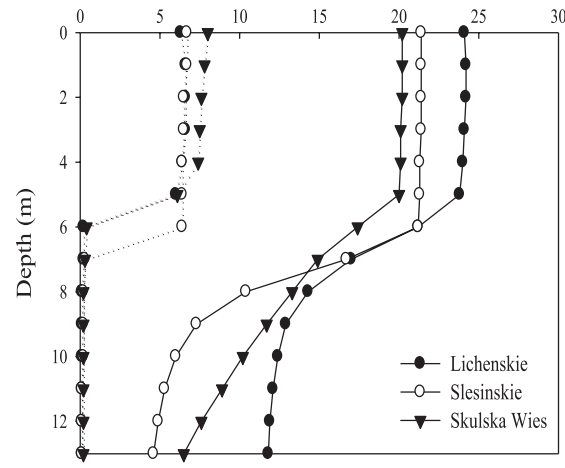

B. Dissolved Oxygen $\left(\mathrm{mg} \mathrm{L}^{-1}\right)$ and Temperature $\left({ }^{\circ} \mathrm{C}\right)$

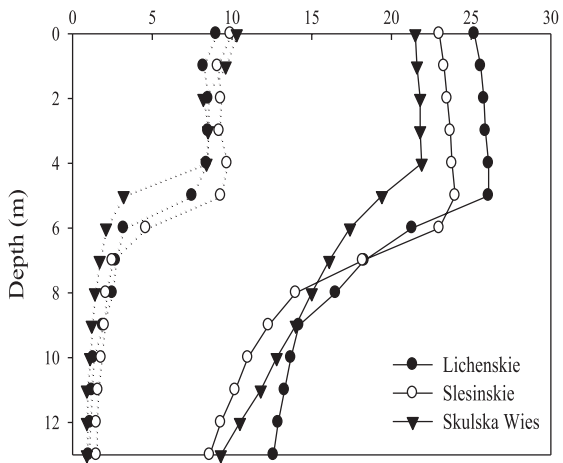

D. Dissolved Oxygen $\left(\mathrm{mg} \mathrm{L}^{-1}\right)$ and Temperature $\left({ }^{\circ} \mathrm{C}\right)$

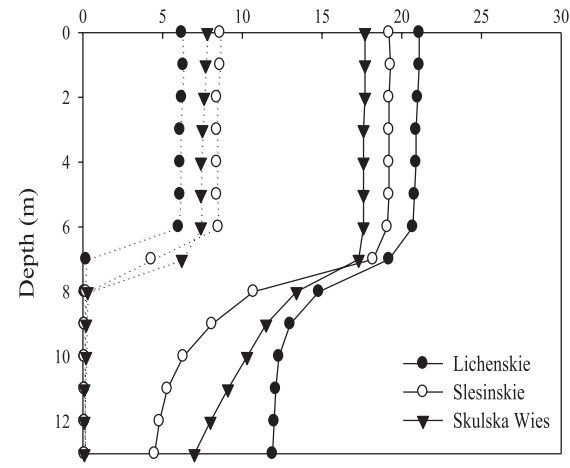

Figure 2. Temperature and oxygen concentration profiles in the three studied lakes. A: 20-22 July, B: 25-27 July, C: 26-28 August, D: 2-4 September. Perfiles de temperatura y de concentración de oxígeno en los tres lagos estudiados. A: 20-22 julio, B: 25-27 julio, C: 26-28 agosto, D: 2-4 septiembre. 
ues. High fish pressure decreases both $F$ and $A$; therefore, we were able to quantify the contribution of both the $A$ and $F$ parameters and determine which factor exerts stronger control over the species population dynamics in the lake. Within each dataset, we used only absolute values because they provide the most reliable insight into the determinants of a population's birth rate dynamics. We estimated bottom-up and top-down effects for two species, Bosmina longirostris and Diaphanosoma brachyurum, that commonly occurred in the studied lakes.

The death rate $(d)$ and intrinsic population growth rate $(r)$ were determined according to Edmondson-Paloheimo models (Paloheimo, 1974):

$$
\begin{aligned}
d & =b-r \\
r & =\left(\ln \left(N_{t}\right)-\ln \left(N_{0}\right) / t\right.
\end{aligned}
$$

where $N_{0}$ and $N_{t}=$ the number of individuals at time 0 and time $t$, respectively.

The population parameters were averaged for the July and August-September sampling periods for each lake (Table 3).

\section{Statistical Analysis}

One-way analysis of variance (ANOVA) or oneway ANOVA based on ranked data (depending on normality) was used to determine whether there were significant differences between the three lakes for temperature, phytoplankton, and zooplankton biomass. We could not apply a repeated measures design for inter-lake comparisons because the lake samplings were staggered, such that the lakes were not sampled on the same dates. Therefore, we used the monthly average data for each of the three stations as replicates to determine whether there were differences between the three lakes during the July and/or August sampling periods individually. However, we did employ repeated measures ANOVA (rm-ANOVA) to conduct intra-lake comparisons to determine whether there were significant temporal changes in each lake regarding temperature and zooplankton biomass (intra-lake comparisons for phytoplankton were not possible because replicates were combined for the July sampling dates; see above). When significant differences were detected, Tukey's Honestly Significant Difference post-hoc comparison test $(p<0.05)$ was used to identify which treatments differed.

We used linear regression to assess the relationships between the biomass of Daphnia and the biomasses of both edible phytoplankton and cyanobacteria. As with the ANOVAs, we compared the data from the July and AugustSeptember sampling periods individually using regressions. All statistical analyses were conducted using Sigma Stat version 3.5.

\section{RESULTS}

\section{Temperature and dissolved oxygen}

The heated lake (Lake Licheńskie) was significantly warmer than the other two lakes, and the secondarily heated lake (Lake Ślesińskie) was warmer than the non-heated lake (Lake Skulska Wieś) during both the July and August sampling periods (ANOVA, $p<0.05$; Tukey's HSD, $p<0.05$ ) (Fig. 2 and 3). All three lakes experienced strong thermal stratification (Fig. 3), with epilimnetic temperatures being highest in the heated lake (Lake Licheńskie) and lowest in the non-heated lake (Lake Skulska Wieś) (Fig. 2 and 3$)$. The average surface temperature in July in Lake Licheńskie was $25.8^{\circ} \mathrm{C}( \pm 0.359)$, compared to $24.6^{\circ} \mathrm{C}( \pm 0.294)$ and $23.1{ }^{\circ} \mathrm{C}$ $( \pm 0.087)$ in Lakes Ślesińskie and Skulska Wieś, respectively. In the August-September sampling period, the average surface temperature in Lake Licheńskie was $22.5^{\circ} \mathrm{C}( \pm 0.217)$, compared to $21.2( \pm 0.182)$ and $19.9( \pm 0.0682)$ in Lakes Ślesińskie and Skulska Wieś, respectively. Temperature differences were also detected through significant rm-ANOVA results, indicating strong intra-lake variation in temperature in each of the three lakes over the course of the experiment (rm-ANOVA, $p<0.001$ for each lake).

The concentrations of dissolved oxygen in the surface layer were relatively similar between the three lakes, varying from 6 to $10 \mathrm{mg} \mathrm{L}^{-1}$ in lakes Licheńskie and Ślesińskie, and from 7 to $13 \mathrm{mg}$ 


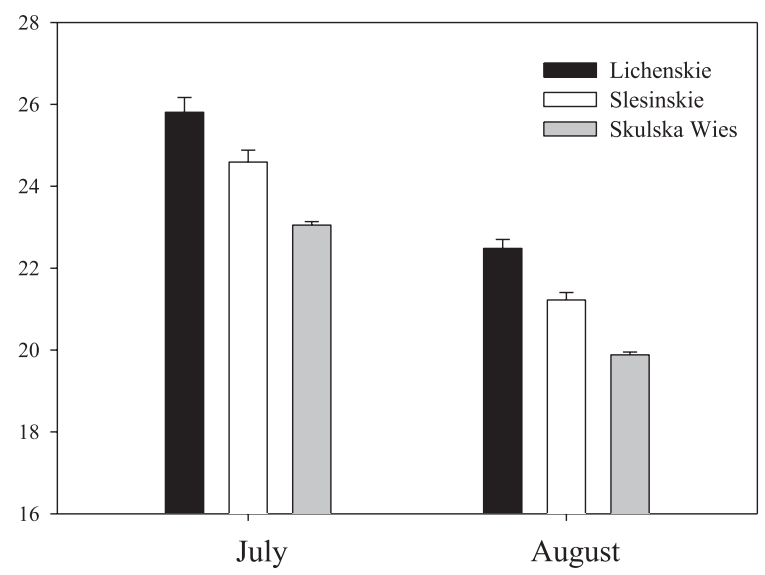

Figure 3. Differences in temperature between the three lakes in July and August. Data from each month were analysed separately using either one-way ANOVA or one-way ANOVA based on ranked data, depending on the normality of the data. All three lakes were significantly different from each other during both sampling periods (ANOVA, $p<0.001$, Tukey's HSD, $p<0.05)$. Error bars represent the standard error of the mean. Diferencias de temperatura entre los tres lagos en julio y agosto. Los datos de cada mes fueron analizados separadamente usando análisis de varianza de una vía (ANOVA, o usando rangos, dependiendo de la normalidad de los datos). Todos los lagos fueron significativamente diferentes entre ellos durante ambos periodos de muestreo (ANOVA, p < 0.001, Tukey's HSD, $\mathrm{p}<0.05$ ). Las barras de error representan el error estándar de la media.

$\mathrm{L}^{-1}$ in Skulska Wieś. A sharp decline in oxygen was observed at 6-7 $\mathrm{m}$ in Lake Licheńskie, at 6$10 \mathrm{~m}$ in Lake Ślesińskie, and at 7-13 $\mathrm{m}$ in Lake Skulska Wieś (Fig. 2).

\section{Cladoceran species composition and biomass}

Three species of Daphnia were observed in the non-heated lake (Lake Skulska Wieś) in July: Daphnia longispina (O. F. Müller), Daphnia hyalina (Leydig), and Daphnia cucullata (Sars). While only two of these species were observed in August-September (D. hyalina and D. cucullata), the total biomass of Daphnia was significantly higher during most of the August-September sampling dates than it was during most of the July sampling dates in the reservoir (rm-ANOVA, Tukey's HSD, $p<0.05$ ). The small-bodied cladocerans that were observed in the non-heated lake were Ceriodaphnia reticulata (Jurine), Diaphanosoma brachyurum
(Liéven), Bosmina coregoni (Baird), and Chydorus sphaericus (O. F. Müller).

Two species of Daphnia were recorded in the secondarily heated lake (Lake Ślesińskie) in July (D. hyalina and D. cucullata). These Daphnia coexisted with several small-bodied species, including $C$. reticulata, D. brachyurum, B. coregoni, Ch. sphaericus, and Bosmina longirostris (O. F. Müller). In August-September, three species of Daphnia were observed (Daphnia galeata (Sars), D. hyalina, and D. cucullata). However, there were no significant differences in Daphnia biomass between the sampling dates over the course of the experiment (rm-ANOVA, Tukey's $p<0.05$ for all intra-lake comparisons in Lake Ślesińskie). Several additional smallbodied species appeared in August-September, including Ceriodaphnia quadrangula (O. F. Müller), Ceriodaphnia pulchella (Sars), Bosmina longispina (Leydig), Pleuroxus aduncus (Jurine), and Bosmina crassicornis (O. F. Müller).

Daphnia were absent from the heated lake (Lake Licheńskie) in July, when the cladoceran community was represented by small-bodied species, including $C$. reticulata, D. brachyurum, and Bosmina longirostris (O. F. Müller). While D. hyalina and D. cucullata were observed in August-September (Fig. 4), intra-lake comparisons showed that the Daphnia biomass did not differ between sampling dates in the heated lake (rm-ANOVA, Tukey's $p<0.05$ for all intra-lake comparisons in Lake Licheńskie).

The highest cladoceran species richness was observed in the secondarily heated lake (Lake Ślesińskie; 13 species), where several species were first observed during August-September. In contrast, in the non-heated lake (Lake Skulska Wieś), no new species were recorded when the temperature declined in August-September, and one species, D. longispina, actually disappeared. The lowest species richness (3 small species) was recorded in Lake Licheńskie in July, when the average temperature was $25.6{ }^{\circ} \mathrm{C}$.

The total biomass of cladocerans was significantly lower in the heated lake (Lake Licheńskie) during the August-September sampling period (ANOVA, $p<0.05$; Tukey's HSD, $p<0.05$; Fig. 4). The biomass of Daphnia responded dif- 

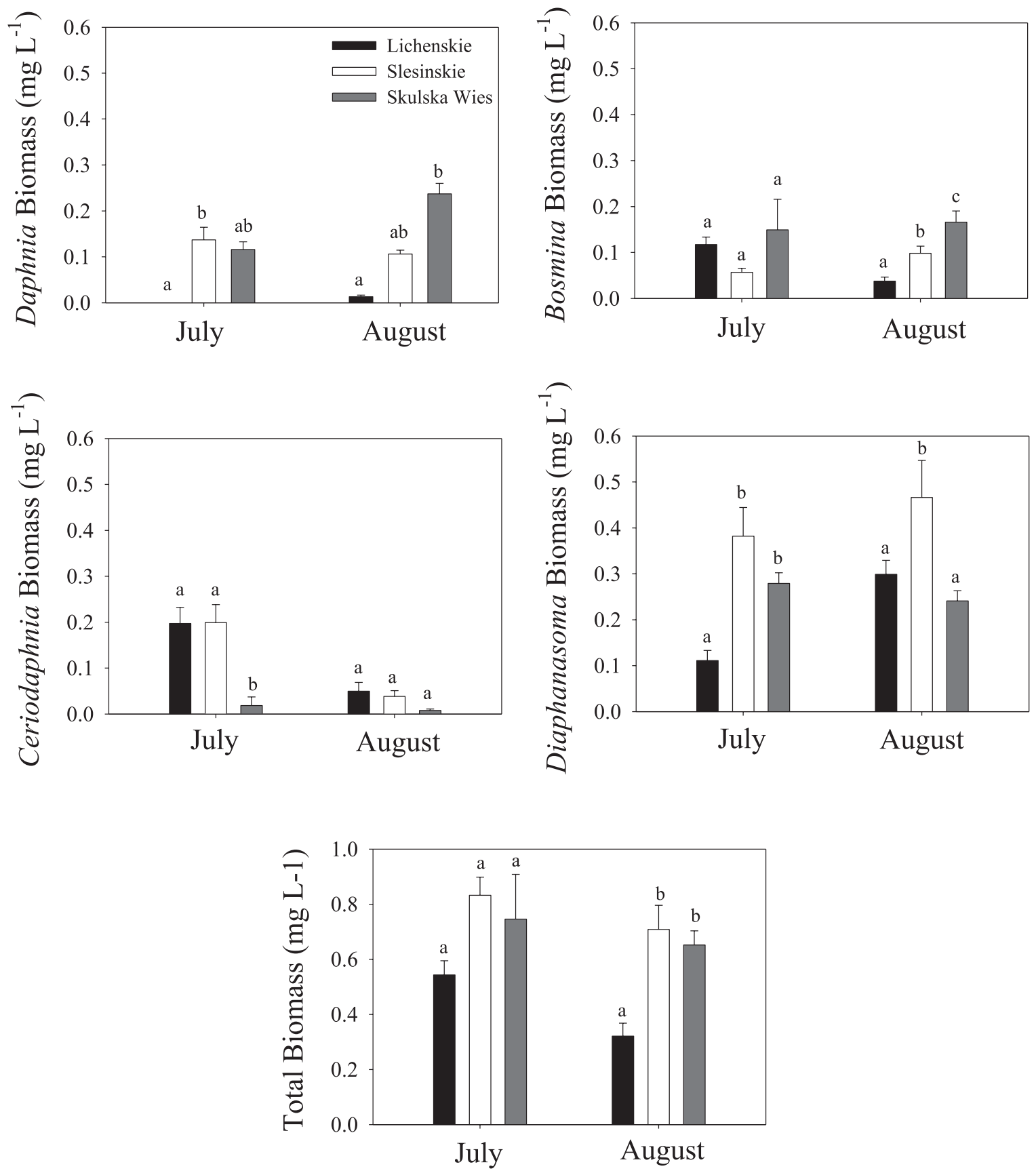

Figure 4. Comparisons of zooplankton biomass between the three study lakes. Data from each month were analysed separately using either one-way ANOVA or one-way ANOVA based on ranked data, depending on the normality of the data. Differences between individual treatments for each sampling period (Tukey's HSD, $p<0.05$ ) are represented by different letters. For example, if two treatments show different letters, they were significantly different from each other for that sampling period. Error bars represent the standard error of the mean. Comparación de la biomasa de zooplancton entre los tres lagos estudiados. Los datos de cada mes fueron analizados separadamente usando análisis de varianza de una vía (ANOVA, o usando rangos dependiendo de la normalidad de los datos). Las diferencias entre cada uno de los tratamientos para cada periodo de muestreo (Tukey's HSD, p < 0.05) están representadas por diferentes letras. Por ejemplo, si dos tratamientos tienen letras diferentes, significa que fueron significativamente diferentes para ese periodo de muestreo. Las barras de error representan el error estándar de la media. 
ferently to changes in temperature between the three lakes. With the decline of the temperature to $22.5^{\circ} \mathrm{C}$ in August-September (a decrease of $3.3{ }^{\circ} \mathrm{C}$ from the July period) in the heated lake (Lake Licheńskie), Daphnia species increased from representing $0 \%$ to $4 \%$ of the total biomass. The biomass of Daphnia species exhibited a greater increase in the non-heated lake (Lake Skulska Wieś), where the temperature in August-September decreased to $20^{\circ} \mathrm{C}$ (a decline of $3.2^{\circ} \mathrm{C}$ from July). The relative biomass of Daphnia in this lake increased from $19 \%$ (July) to $36 \%$ (August-September); this was the only lake in which there was a significant increase in Daphnia in August (rm-ANOVA, $p<0.001$ ). In the secondarily heated lake (Lake Ślesińskie), the relative biomass of Daphnia was $19 \%$, compared to $15 \%$ in August-September.

In contrast, the biomass of Ceriodaphnia sp. tended to decrease with cooling temperatures in the heated and secondarily heated lakes (Fig. 4). When the three lakes were compared, the biomass of Ceriodaphnia sp. was found to be significantly higher in the heated (Lake Licheńskie) and secondarily heated (Lake Ślesińskie) lakes than it was in the non-heated Lake (Lake Skulska Wieś) in July (ANOVA, $p<0.001$; Fig. 4). Intra-lake comparisons showed that the Ceriodaphnia biomass did not decrease with decreasing temperatures in the non-heated lake (Lake Skulska Wieś) (Tukey's HSD, $p<0.05$ for all intra-lake comparisons between dates). In contrast, Ceriodaphnia decreased in both the heated (Lake Licheńskie) and secondarily heated (Lake Ślesińskie) lakes as temperatures decreased in August-September (rm-ANOVA, $p<0.05$ for both lakes).

The biomass of Bosmina sp. and Diaphanasoma sp. did not appear to be directly related to temperature (Fig. 4). The highest biomass of Diaphanasoma sp. was observed in the secondarily heated lake (Lake Ślesińskie), where it was significantly higher compared to the heated lake (Lake Licheńskie) in July and both the heated and non-heated lakes in August-September (ANOVA, $p<0.001$; Tukey's HSD, $p<0.05$; Fig. 4). The highest biomass of Bosmina $s p$. was observed in the non-heated lake (Skulska Wieś) in

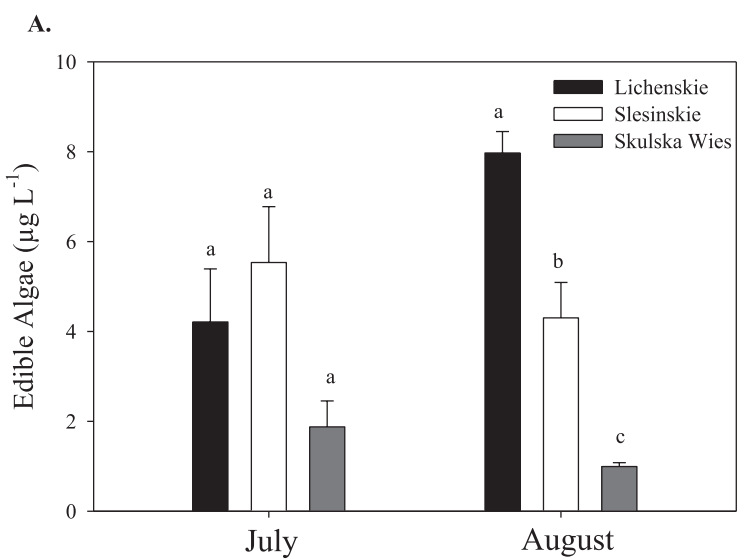

B.

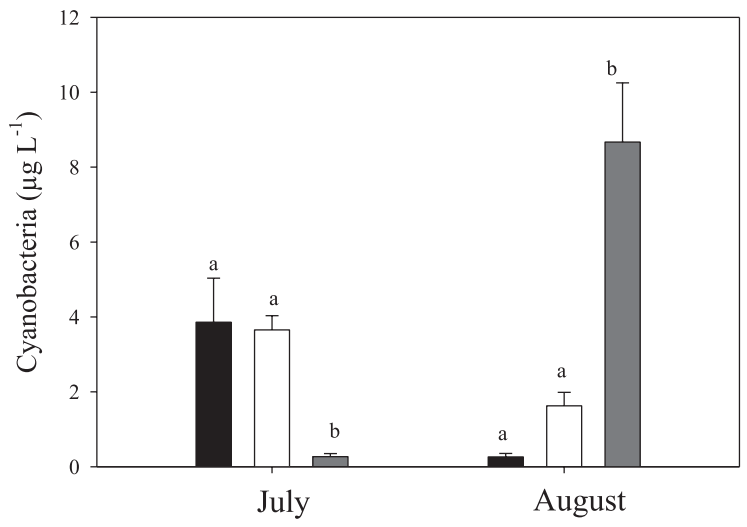

Figure 5. Total biomass of edible phytoplankton $(<40 \mu \mathrm{m})$ (A) and cyanobacteria (B) in the three studied lakes in July and August-September. Differences between individual treatments for each sampling period (Tukey's HSD, $p<0.05$ ) are represented by different letters. Error bars represent the standard error of the mean. Biomasa total de fitoplancton comestible $(<40 \mu \mathrm{m})($ A) y cianobacterias (B) en los tres lagos estudiados en julio y agosto-septiembre. Las diferencias entre cada uno de los tratamientos para cada periodo de muestreo (Tukey's HSD, $\mathrm{p}<0.05)$ están representadas por diferentes letras. Las barras de error representan el error estándar de la media.

August, when it was significantly higher than in the heated and secondarily heated lakes (ANOVA, $p<0.001$; Tukey's HSD, $p<0.05$; Fig. 4). The biomasses of Bosmina and Diaphanasoma did not show strong intra-lake differences over the course of the sampling periods in any of the three lakes.

\section{Fecundity}

Fecundity, which is an indicator of food conditions, was similar among Daphnia and the small- 
bodied cladocerans (Table 3). Moreover, fecundity was relatively similar between the two sampling periods. In general, fecundity was lower in the non-heated lake (Lake (Skulska Wieś) than it was in the heated (Lake Licheńskie) and secondarily heated (Lake Ślesińskie) lakes (Table 3). In all cases, food conditions appeared to support reproducing populations.

\section{Death rate}

The observed death rates changed from July to August-September: the rate increased by 0.04 in the heated lake (Lake Licheńskie) and decreased by 0.03 in both the secondarily heated lake (Lake Ślesińskie) and non-heated lake (Lake Skulska Wieś). The highest average death rate was observed in Lake Licheńskie, an intermediate average death rate was observed in Lake Ślesińskie, and the lowest average death rate was observed in Lake Skulska Wieś (Table 3). In July, the ratio of the average death rates of cladocerans was 4.4: 3.8: 1 for Lakes Licheńskie : Ślesińskie : Skulska Wieś, respectively. In August-September, the ratio between Lakes Licheńskie and Ślesińskie remained similar, while the difference in the average death rate in Lake Skulska Wieś compared to the other two lakes increased to $13: 8: 1$ for Lakes Licheńskie:Ślesińskie:Skulska Wieś, respectively. Therefore, in Lake Skulska Wieś, the death rate exhibited a larger decrease with cooling from the July period to August-September compared to the other two lakes.

\section{Population growth rates among cladoceran species}

In July, the cladoceran population growth rates $(r)$ were negative in the heated lake (Lake Licheńskie), but positive in both the non-heated (Lake Skulska Wieś) and secondarily heated (Lake Ślesińskie) lakes (Table 3). While the population growth rates of both Daphnia sp. and small cladocerans increased in Lakes Ślesińskie and Skulska Wieś, the increase was greater in Lake Skulska Wieś.

In August-September, population growth rates increased slowly in Lake Licheńskie, main- ly due to the appearance of Daphnia sp., while in Lake Ślesińskie, growth rates declined. In Lake Skulska Wieś, there was a small, gradual increase in the population growth rate of Daphnia species relative to the population growth rate of smallbodied species (Table 3 ).

\section{Phytoplankton}

While there were no differences in the edible fractions recorded in the three lakes $(<40 \mu \mathrm{m})$ during July (ANOVA, $p>0.05$ ), the biomass of edible algae was significantly lower in the non-heated lake (Lake Skulska Wieś) than it was in the other two lakes (ANOVA, $p<0.001$; Tukey's HSD, $p<0.05$; Fig. 5a) in August-September. Edible biomass was also significantly lower in the secondarily heated lake (Lake Ślesińskie) than it was in the heated lake (Lake Licheńskie) in August-September (ANOVA, $p<0.001$; Tukey's HSD, $p<0.05$; Fig. 5a). Regression analysis showed that as the edible algal biomass increased, Daphnia biomass decreased in the three lakes in August-September (Edible Biomass $_{(\mathrm{Aug})}=7.783+29.09($ Daphnia Biomass $\left.\left._{(\mathrm{Aug})}\right) ; r^{2}=0.85, p<0.001\right)$. Thus, our data from the three lakes do not support the hypothesis that enhanced temperatures caused a greater decline of algal food resources compared to lower temperatures.

The biomass of cyanobacteria (blue-greens) also varied in the lakes (Fig. 5b). In July, the biomass of cyanobacteria was significantly higher in the both the heated (Lake Licheńskie) and secondarily heated (Lake Ślesińskie) lakes compared to the non-heated lake (Lake Skulska Wieś) (ANOVA, $p<0.001$; Tukey's HSD, $p=0.015$; Fig. 5b). In August-September, the opposite trend was observed, with the cyanobacteria biomass being significantly higher in the non-heated lake than it was in the other two lakes (ANOVA, Tukey's HSD, $p<0.05$; Fig. $5 b)$. There was a significant positive relationship detected between the biomass of Daphnia and the biomass of cyanobacteria in August-September in the three lakes (Cyano Biomass $_{(\mathrm{Aug})}=-1.096+38.90$ (Daphnia $\left.\operatorname{Biomass}_{(\text {Aug })} ; r^{2}=0.85, p<0.001\right)$. 


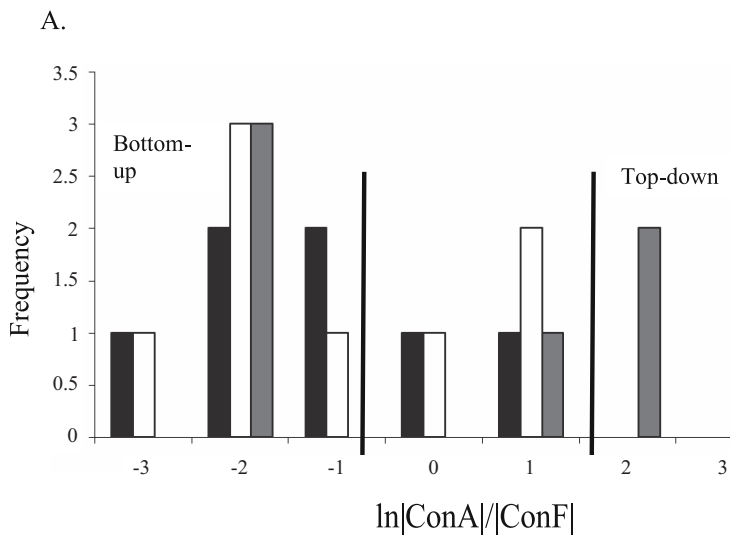

B.

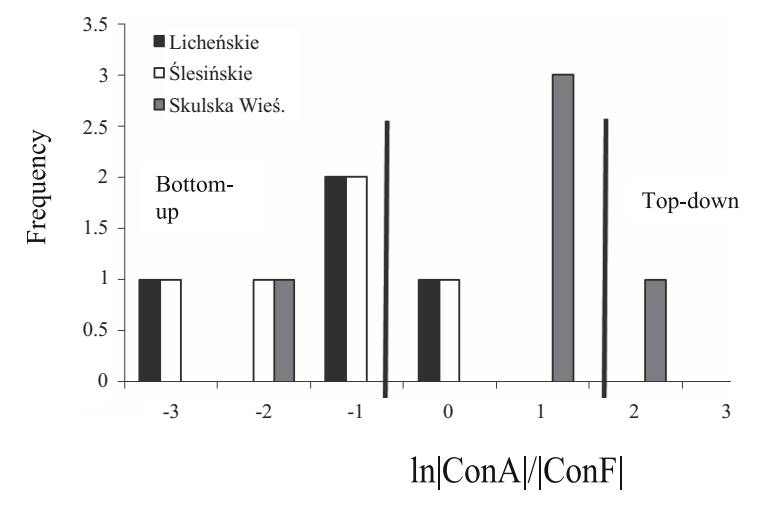

Figure 6. Ratio of the $\mid$ Con $A|/|$ Con $F \mid$ contributions, where Con $A$ is the contribution of $A$, which is $N_{a} / N$, or the proportion of adults within the whole population $N$ (juveniles plus adults), and Con $F$ is the contribution of $F$, which is $E / N_{a}$, or the fecundity, i.e., the number of eggs, $E$, over the number of adults, $N_{a}$. The borders of top-down and bottom-up control areas are presented according to Polishchuk et al. (2012). A: Bosmina sp., B: D. brachyurum. Tasa de las contribuciones $\mid$ Con $\mathrm{A}|/|$ Con $\mathrm{F} \mid$, donde Con $\mathrm{A}$ es la contribución de $\mathrm{A}$, es decir $\mathrm{N}_{\mathrm{a}} / \mathrm{N}$, o la proporción de adultos dentro de la población total $\mathrm{N}$ (juveniles y adultos), y Con $\mathrm{F}$ es la contribución de $\mathrm{F}, \mathrm{E} / \mathrm{N}_{\mathrm{a}}$, o la fecundidad, es decir, el número de huevos, E, sobre el número de adultos, $\mathrm{N}_{\mathrm{a}}$. Las fronteras entre las áreas de control top-down y bottom-up se presentan de acuerdo a Polishchuk et al. (2012). $A$ : Bosmina sp., B: D. brachyurum.

\section{Contribution analysis of top-down (predation) and bottom-up (food) effects}

Methods developed by Polishchuk (1995) and Polishchuk et al. (2012) to estimate the effects of top-down and bottom-up factors on birth rates of cladoceran species were applied in this study (Fig. 6). Substantial effects of food conditions were mostly associated with the birth rates in Lakes Lichenskie and Ślesińskie and the fraction of adults affected by predators in Lake Skulska Wieś. These data suggest that predation had a greater controlling effect on cladocerans (both Bosmina sp. and D. brachyurum, Fig. 6a, b) in the non-heated lake compared to the two other lakes.

\section{DISCUSSION}

Cladoceran species are effective dispersers, which can be important for restoring community functioning after disturbances (Bonacina \& Pasteris, 2001). The lakes investigated in the current study are located at a distance of approximately $5 \mathrm{~km}$ from each other, and Lakes Licheńskie and Ślesińskie are connected by a canal. Cladocerans are known to actively disperse within a distance of $100 \mathrm{~km}$ and are able to invade nearby lakes, provided that biotic or abiotic factors do not hinder their development (Shurin et al., 2000, Shurin, 2000, Havel \& Shurin, 2004). Therefore, we assumed that there was a strong potential for the exchange of cladoceran taxa between the three study lakes. However, the composition and biomass of cladocerans differed between the three lakes. We suggest that the causes of these differences are at least in partly related to the different temperatures of the three lakes. Because temperature can influence cladoceran community structure either directly or indirectly, comparative analysis of the biomass of cladoceran species, population parameters, including fecundity, death, and population growth rates, and food conditions (phytoplankton) as well as contribution analysis of top-down and bottom-up effects (Polishchuk et al., 2012) can help to determine the factors responsible for the observed cladoceran community structure in the studied lakes.

In Lakes Ślesińskie and Licheńskie, cladocerans constituted approximately $60-80 \%$ of the total zooplankton biomass (Tunowski, 1994). Total biomass is often related to the diversity of zooplankton and cladocerans. When a greater number of species are present, the biomass in that communities tends to be higher as well. Such positive relationships between diversity and abundance have been well documented for a variety of trophic groups (Cardinale et al., 
2006). With respect to zooplankton, Lennon et al. (2003) showed that zooplankton biomass increased with increasing diversity. Similarly, in the current study the greatest biomass of cladocerans was recorded in the lake with the highest richness (e.g., Lake Ślesińskie), while the lowest biomass was recorded in the lake with the fewest species (e.g., Lake Licheńskie). The lower biomass and species richness observed in Lake Licheńskie compared to the two colder lakes were consistent with previous studies in these lakes (Tunowski \& Sergiejewa, 1998; Tunowski, 2009a). The biomass of a population has been suggested to be an indicator of population fitness in an ecosystem (Kmet \& Straškraba, 2004); based on this assumption, the fittest community of cladocerans likely occurred in Lake Ślesińskie under intermediate summer temperatures.

One of the possible causes of declines in cladoceran diversity can be food deficits. Food depletion is usually observed when the abundance of zooplankton reaches its peak, resulting in a so-called clear-water phase (Scheffer \& Rinaldi, 2000). When this occurs, superior competitors can displace taxa that exhibit a higher threshold food concentration than ambient food levels (Hülsmann et al., 2005). Because the fecundity of both large and small species in the three study lakes was greater than one egg per adult female, mortality caused by a lack of resources was not likely, which is supported by the contribution analysis of body mass dynamics in cladocerans. It has been shown that Daphnia species can alter their distribution of consumed energy between different organismal functions (Polishchuk \& Vijverberg, 2005). If the food concentration does not restrain individual development, consumed energy is expended to support reproduction. While the food concentration gradually decreases, the share of energy consumed for reproduction correspondingly decreases, and a greater percentage of energy is expended on individual growth and survival. Such a mechanism allows individuals to survive under conditions of food depletion, postponing reproductive processes until resource levels increase. Hence, we suggest that the enhanced death rate observed in the heated lake was not connected to the food concentration because it was sufficiently high to support reproductive processes. In support of this notion, Gliwicz et al. (2000) showed that the population densities of cladocerans remained far below the carrying capacity and did not depend on the food concentration in a study of three neighbouring and interconnected lakes in northern Poland (Gliwicz et al., 2000). In the present study, the fecundity of cladoceran populations was even higher in the heated lake, demonstrating that food conditions were more favourable there than in the other two lakes. Theoretical models of global warming also predict increases in the biomass of primary producers (Petchey et al., 1999), thus supporting such a view.

Fish pressure is also unlikely to be greater in the heated lake. In Lakes Licheńskie and Ślesińskie, the fish species assemblages were similar due to their close proximity and interconnection via canals. The most abundant fishes in these lakes are roach (Rutilus rutilus (L.)) and bleak (Alburnus alburnus (L.)) (Tereshchenko et al., 2007a), and there are more planktivorous fish in Lake Ślesińskie than in Lake Licheńskie (Tereshchenko et al., 2007b). The contribution analysis according to Polishchuk et al. (2012) showed that cladocerans were controlled more strongly by top-down factors in Lake Skulska Wieś and by bottom-up factors in Lakes Licheńskie and Ślesińskie. Hence, predation is unlikely to be responsible for the lower cladoceran biomass and lower species richness in the heated lake (Lake Licheńskie).

Another factor that may negatively affect the development of Daphnia populations is the presence of cyanobacteria, which generally present low nutritional food quality and, in some cases, are toxic (Arnold, 1971; De Pauw \& Pruder, 1986; Lampert, 1987; Ahlgren et al., 1990). Additionally, filamentous algae can mechanically block the filtration activity of large-bodied species (Hayward \& Gallup, 1976; Webster \& Peters, 1978; Gliwicz \& Lampert, 1990; Repka, 1996). However, while cyanobacteria were most abundant in Lake Skulska Wieś in AugustSeptember, the biomass of Daphnia in this lake exceeded that in the other two studied lakes, where cyanobacteria were less abundant during 
the study period. The abundance of cyanobacteria in Lake Licheńskie began to decline after the lake was first employed as a cooling reservoir in 1958. Fourteen years later, the phytoplankton communities were often dominated by diatoms and green algae (Hilbricht-Ilkowska \& Zdanowski, 1978). However, dominance in the cladoceran community shifted from Daphnia to small-bodied species over the same time period. Similarly, edible phytoplankton were more abundant, while cyanobacteria were less abundant in August-September in Lake Licheńskie relative to the other two lakes. However, Daphnia species were rare or absent in this lake, suggesting that the hypothesis that cyanobacteria hamper the development of Daphnia populations was not supported in the current study.

Zooplankton mortality can also be dependent on the retention time of a lake. In Lake Licheńskie, the retention time was 3-5 days on average, compared to 5-7 days in Lake Ślesińskie (Stawecki et al., 2007). Mortality can also be high for animals in the canals connecting the lakes and the power plant. For example, biomass losses in the canals can surpass $90 \%$, and those among cladoceran populations can reach $100 \%$ (Tunowski, 1988, 2009b). Therefore, the higher mortality observed in Lakes Licheńskie and Ślesińskie may be related to their flowing canals, in contrast to the situation in Lake Skulska Wieś. However, the mortality rates caused by canal systems should be equal for all cladoceran species, and there is no reason to believe that the taxa that were successful in these lakes (e.g., $C$. reticulata and $D$. brachyurum) were more flow resistant than the Daphnia species.

Cladoceran species were affected by temperature in the three study lakes. Ceriodaphnia tended to exhibit the highest biomass under the warmest conditions in July in the heated (Lake Licheńskie) and secondarily heated (Lake Ślesińskie) lakes. In contrast, the biomass of Daphnia was lowest in the warmest lake in July, and the biomass of this genus increased in the non-heated lake only as it cooled in August-September. The biomass of Bosmina and $D$. brachyurum did not appear to show any relationship with temperature. Therefore, we can hypothesise that small-bodied species are better adapted to higher temperatures. However, the biomass of algae was higher in the heated and secondarily heated lakes than in the non-heated lake, thereby providing conditions for sustaining higher biodiversity at enhanced temperatures. The results of the present study are in general agreement with the theoretical model proposed by Petchey et al. (1999) suggesting that various trophic levels respond differently to increases in temperature. The biomass of primary producers increases, while the biomass of higher trophic levels, including herbivorous zooplankton, declines. Simultaneously, the biodiversity of higher trophic levels decreases at higher temperatures. Such responses of lower trophic levels are likely to serve as adaptive mechanisms for sustaining the structure and biomass of higher trophic levels under warming.

\section{ACKNOWLEDGMENTS}

We are grateful to J. Ejsmont-Karabin, J. Uchmanski, and I. Sawicka for constant assistance and providing the opportunity to perform studies at the Hydrobiological Station belonging to the Center for Ecological Research of the Polish Academy of Sciences in Mikolajki. This work was supported by the Polish Ministry of Sciences and Higher Education and the Russian and Belorussian Foundation for Basic Research.

\section{REFERENCES}

ACHENBACH, L. \& W. LAMPERT. 1997. Effects of elevated temperatures on threshold food concentrations and possible competitive abilities of differently sized cladoceran species. Oikos, 79: 469476.

AHLGREN, G., L. LUNDSTEDT, M. BRETT \& C. FORSBERG. 1990. Lipid composition and food quality of some freshwater phytoplankton for cladoceran zooplankters. Journal of Plankton Research, 12: 809-818.

ARNOLD, D. E. 1971. Ingestion, assimilation, survival, and reproduction by Daphnia pulex fed seven species of blue-green algae. Limnology and 
Oceanography, 16: 906-920.

ATKINSON, D. 1994. Temperature and organism size a biological law for ectotherms? Advances in Ecological Research, 25: 1-58.

BALUSHKINA, E. B. \& G. G. WINBERG. 1978. Relationship between body mass and its length on plaktonic animals. In: Experimentalnye $i$ polevye issledovania biologicheskich osnov produktivnosti ozer. G. G. Winberg (eds.): 58-72. Nauka, Leningrad.

BEISNER, B. E., McCAULEY \& F. J. WRONA. 1997. The influence of temperature and food chain length on plankton predator-prey dynamics. Canadian Journal of Fisheries and Aquatic Sciences, 54: 586-595.

BLOEM, J. \& J. VIJVERBERG. 1984. Some observations on the diet and food selection of Daphnia hyalina (Cladocera) in an eutrophic lake. Hydrobiological Bulletin, 18: 39-45.

BONACINA, C.\& A. PASTERIS. 2001. Zooplankton of Lake Orta after liming: an eleven years study. Journal of Limnology, 60: 101-109.

CARDINALE, B. J., D. S. SRIVASTAVA, J. E. DUFFY, J. P. WRIGHT, A. L. DOWNING, M. Sankaran \& C. JOUSSEAU. 2006. Effects of biodiversity on the functioning of trophic groups and ecosystems. Nature, 443: 989-992.

DAWIDOWICZ, P. 1990. The effect of Daphnia on filament length of blue-green algae. Hydrobiologia, 191: 265-268.

DE PAUW, N. \& G. PRUDER. 1986. Use and production of algae as food in aquaculture: practice, problems and research needs. In: Realism in Aquaculture: Achievements, Constrains, Perspectives. Rosenthal, H \& C.J. Sinderman (eds.): 77-106. European Aquaculture Society, Bredene, Belgium.

EJSMONT-KARABIN, J. \& T. WÊGLEÑSKA. 1988. Spatial distribution of the zooplankton and its population features in two lakes of different heatedwater through-flow. Ekologia Polska, 36: 203-230.

FENIOVA, I. YU, A. L. PALASH, V. I. RAZLUTSKIJ, A. R. DZIALOWSKI. 2013. Effects of temperature and resource abundance on smalland large-bodied cladocerans: Community stability and species replacement. Open Journal of Ecology, 3(2): 164-171.

FINLAY, K. P., H. CYR \& B. J. SHUTER. 2001. Spatial and temporal variability in water temperatures in the littoral zone of a multibasin lake. Canadian Journal of Fisheries and Aquatic Sciences, 58: 609-619.
GEORGE, D. G. \& G. P. HARRIS. 1985. The effect of climate on long-term changes in the crustacean zooplankton biomass of Lake Windermere, U. K. Nature, 316: 536-539.

GILLOOLY, J. F., E. L. CHARNOV, G. B. WEST, V. M. SAVAGE \& J. H. BROWN. 2002. Effects of size and temperature on developmental time. Nature, 417: 70-73.

GLIWICZ, Z. M., A. E. RUTKOWSKA \& J. WOJCIECHOWSKA. 2000. Daphnia populations in three interconnected lakes with roach as the principal planktivore. Journal of Plankton Research, 22 (8): 1539-1557.

GLIWICZ, Z. M. 2003. Between hazards of starvation and risk of predation: the ecology of offshore animals. In: Excellence in Ecology, 12. O. Kinne (ed.). International Ecology Institute, Germany, Oldendorf/Luhe.

GLIWICZ,Z. M. \& W. LAMPERT. 1990. Food thresholds in Daphnia species in the absence and presence of blue-green filaments. Ecology, 71: 691-702.

GLIWICZ, Z. M. \& J. PIJANOWSKA. 1989. The role of predation in zooplankton succession. In: Plankton Ecology: Succession in Plankton Communities. Sommer, U (ed.): 195-252. Springer-Verlag, New York.

GYLLSTRÖM, M., L. A. HANSSON, E. JEPPESEN, F. GARCÍA-CRIADO, E. GROSS, K. IRVINE et al. 2005. The role of climate in shaping zooplankton communities of shallow lakes. Limnology and Oceanography, 50: 2008-2021.

HAVEL, J. E. \& J. B. SHURIN. 2004. Mechanisms, effects, and scales of dispersal in freshwater zooplankton. Limnology and Oceanography, 49: 1229-1238.

HAYWARD, R. S. \& D. N. GALLUP. 1976. Feeding, filtering and assimilation in Daphnia schoedlen SARS as affected by environmental conditions. Archiv für Hydrobiologie, 77: 139-163.

HILLBRICHT-ILKOWSKA, A. \& B. ZDANOWSKI. 1978. Effect of thermal effluents and retention time on lake functioning and ecological efficiencies in plankton communities. Internationale Revue gesamten Hydrobiologie, 63: 609-617.

HILLBRICHT-ILKOWSKA, A. \& B. ZDANOWSKI. 1988. Main changes in the Konin lake system (Poland) under the effect of heated-water discharge pollution and fishery. Ekologia Polska, 36: 23-45. 
HOLZAPFEL, A. M. \& R. D. VINEBROOKE. 2005. Environmental warming increases invasion potential of alpine lake communities by imported species. Global Change Biology, 11: 2009-2015.

KARLSSON, J, A. JONSSON \& M. JANSSON. 2005. Productivity of high latitude lakes: climate effect inferred from altitude gradient. Global Change Biology, 11: 710-715.

KMET, T. \& M. STRAŠKRABA. 2004. Feeding adaptations of filter feeders: Daphnia. Ecological Modelling, 178: 313-327.

LAMPERT, W. 1987. Laboratory studies on zooplankton-cyanobacteria interactions. New Zealand Journal of Marine and Freshwater Research, 21: 483-490.

LENNON, J. T., V. H. SMITH \& A. R. DZIALOWSKI. 2003. Invasibility of plankton food webs along a trophic state gradient. Oikos, 102: 191-203.

LENNON, J. T., V. H. SMITH \& K. WILLIAMS. 2001. Influence of temperature on exotic Daphnia lumholtzi and implications for invasion success. Journal of Plankton Research, 23: 425-434.

MAGNUSON, J. J., K. E. WEBSTER, R. A. ASSEL, C. J. BOWSER, P. J. DILLON, J. G. EATON et al. 1997. Potential effects of climate changes on aquatic systems: Laurentian Great Lakes and Precambrian Shield Region. Hydrological Processes, 11: 825-871.

MCKEE, D., D. ATKINSON, S. COLLINGS, J. EATON, I. HARVEY, T. HEYES et al. 2002. Macro-zooplankter responses to simulated climate warming in experimental freshwater microcosms. Freshwater Biology, 47: 1557-1570.

MEERHOFF, M., C. IGLESIAS, F. TEIXEIRA DE MELLO, J. M. CLEMENTE, E. JENSEN, T. L. LAURIDSEN \& E. JEPPESEN. 2007. Effects of habitat complexity on community structure and predator avoidance behaviour of littoral zooplankton in temperate versus subtropical shallow lakes. Freshwater Biology, 52: 1009-1021.

MOORE, M. V., C. L. FOLT \& R. S. STEMBERGER. 1996. Consequences of elevated temperatures for zooplankton assemblages in temperate lakes. Archiv für Hydrobiologie, 135: 289-319.

NAPIÓRKOWSKA-KRZEBIETKE, A. 2009. Diversity and dynamics of phytoplankton in lakes Licheńskie and Ślesińskie in 2004-2005. Archives of Polish Fisheries, 253-265.
OLDEN, J. D., D. A. JACKSON, P. D. PERES-NETO. 2001. Spatial isolation and fish communities in drainage lakes. Oecologia, 127: 572-585.

PALOHEIMO, J. E. 1974. Calculation of instantaneous birth rate. Limnology and Oceanography, 19: 692-694.

PATALAS, K. 1967. Produkoja pierwotna i wtórna planktonu w jeziorze ogrzewanym przez 1967 elektrowni ciepln?. [Primary and secondary production of plankton in lake heated by electricity power plant.] Summary report on 7th Polish Hydrobiologists Congress in Świnoujscie, September 1967.

PETCHEY, O. L., P. T. MCPHEARSON, T. M. CASEY \& P. J. MORIN. 1999. Environmental warming alters food-web structure and ecosystem function. Nature, 402: 69-72.

PINTO-COELHO, R., B. PINEL-ALLOUL, G. METHOT \& K. E. HAVENS. 2005. Crustacean zooplankton in lakes and reservoirs of temperate and tropical regions: variation with trophic status. Canadian Journal of Fisheries and Aquatic Sciences, 62: 348-361.

PÓłTORACKA-SOSNOWSKA, J. 1967. Skład gatunkowy fitoplanktonu w jeziorach o temperaturze 1967 sztucznie podwyźszonej i normalnej. [Composition by species of phytoplankton in lakes with normal and artificially raised temperatures.] Summary Report on 7th Polish Hydrobiologists Congress in Świnoujście, September 1967.

POLISHCHUK, L. V. 1995. Direct positive effect of invertebrate predators on birth rate in Daphnia studied with a new method of birth rate analysis. Limnology and Oceanography, 40: 483-489.

POLISHCHUK, L. V. \& J. VIJVERBERG. 2005. Contribution analysis of body mass dynamics in Daphnia. Oecologia, 144: 268-277.

POLISHCHUK, L. V., J. VIJVERBERG, D. A. VORONOV \& W. M. MOOIJ. 2012. How to measure top-down vs bottom-up effects: a new population metric and its calibration on Daphnia. Oikos. Article first published online: 13 DEC 2012, DOI: 10.1111/j.1600-0706.2012.00046.x

REPKA, S. 1996. Inter- and intraspecific differences in Daphnia life histories in response to two food sources: the green alga Scenedesmus and the filamentous cyanobacterium Oscillatoria. Journal of Plankton Research, 18: 1213-1223.

SARMA, S. S. S., S. NANDINI \& R. D. GULATI. 2005. Life history strategies of cladocerans: com- 
parisons of tropical and temperate taxa. Hydrobiologia, 542: 315-333.

SCHEFFER, M. \& S. RINALDI. 2000. Minimal models of top-down control of phytoplankton. Freshwater Biology, 45: 265-283.

SHURIN, J. B., J. E. HAVEL, M. A. LEIBOLD \& B. PINEL-ALLOUL. 2000. Local and regional zooplankton species richness: a scale-independent test for saturation. Ecology, 81: 3062-3073.

SHURIN, J. B. 2000. Dispersal limitation, invasion resistance, and the structure of pond zooplankton communities. Ecology, 81: 2348-2357.

SINICYNA, O. O., A. A. PROTASOV, B. ZDANOWSKI \& A. KRASZEWSKI. 2001. Ecological niche of Dreissena polymorpha (Pall.) aggregations in the heated Konin lakes system. Archives of Polish Fisheries, 9: 133-142.

STAWECKI, K, J. P., PYKA \& B. ZDANOVSKI. 2007. The thermal and oxygen relationship and water dynamics of the surface layer in the Konin heated lakes ecosystems. Archives of Polish Fisheries, 15: 247-258.

STRECKER, A. L., T. P. COBB \& R. D. VINEBROOKE. 2004. Effects of experimental greenhouse warming on phytoplankton and zooplankton communities in fishless alpine ponds. Limnology and Oceanography, 49: 1182-1190.

TERESHCHENKO, V. G., A. KAPUSTA, H. WILKONSKA \& A. P. STRELNIKOVA. 2007a. Longterm changes in $0+$ fish assemblages of heated lakes. I. Using phase diagrams to evaluate changes in ichthyofauna. Archives of Polish Fisheries, 15: 415-430.
TERESHCHENKO, V. G., A. KAPUSTA, H. WILKONSKA \& A. P. STRELNIKOVA. 2007b. Longterm changes in $0+$ fish assemblages in littoral zones of heated lakes. II. Biodiversity of ichthyofauna structure. Archives of Polish Fisheries, 15: 431-443.

TUNOWSKI, J. 1988. Zooplankton losses during the passing through the cooling system of a power station. Ekologia Polska, 36: 231-243.

TUNOWSKI, J. 1994. The effect of heating and water exchange on the zooplankton composition in heated Konin lakes. Archives of Polish Fisheries, 2: 235-255.

TUNOWSKI, J. 2009. Zooplankton structure in heated lakes with differing thermal regimes and water retention. Archives of Polish Fisheries, 17: 291303.

TUNOWSKI, J. \& O. A. SERGIEJEWA. 1998. Zooplankton in the lakes and channels that comprise the cooling system for the Konin and Patnów power plants. Biblioteka Monitoringu Środowiska, Konin: 37-39.

TUNOWSKI, J. 2009a. Zooplankton structure in heated lakes with differing thermal regimes and water retention. Archives of Polish Fisheries, 17: 291-303.

TUNOWSKI, J. 2009b. Changes in zooplankton abundance and community structure in the cooling channel system of the Konin and Pạtnów power plants. Archives of Polish Fisheries, 17: 279-289.

WEBSTER, K. E. \& R. H. PETERS. 1978. Some size-dependent inhibitions of larger cladoceran filterers in filamentous suspensions. Limnology and Oceanography, 23: 1238-1245. 